\title{
Body and Emotion
}


University of Pennsylvania Press

SERIES IN CONTEMPORARY ETHNOGRAPHY

Dan Rose and Paul Stoller, General Editors

A complete listing of the books in this series appears at the back of this volume 


\section{Body and Emotion}

The Aesthetics of Illness and

Healing in the Nepal Himalayas

\section{Robert R. Desjarlais}

uph

University of Pennsylvania Press

Philadelphia 
Copyright $\mathcal{C} 1992$ by the University of Pennsylvania Press

All rights reserved

Printed in the United States of America

\section{Library of Congress Cataloging-in-Publication Data}

Desjarlais, Robert R.

Body and emotion: the aesthetics of illness and healing in the Nepal Himalayas / Robert R. Desjarlais.

p. $\mathrm{cm} .-$ (Series in contemporary ethnography)

Includes bibliographical references and index.

ISBN 0-8122-3166-X - ISBN 0-8122-1434-X (paper)

I. Shamanism-Nepal-Helmu Region. 2. Sherpa (Nepalese people)-Religion.

3. Helmu Region (Nepal) - Religious life and customs. I. Title. II. Series.

BL2033.5.S52D45 1993

$299^{\prime} .54$-de20 
If we had a keen vision of all ordinary human life, it would be like hearing the grass grow or the squirrel's heart beat, and we should die of that roar which lies on the other side of silence.

George Eliot Middlemarch

sdod na sems pa tsher $k a$ 'thon na rkang chung na tsha rkang chung na gi gi 'dug su shi gang la bshad byung

If we stay our hearts will ache, If we go our little feet will hurt the sorrow of little feet hurting, to whom can we tell?

Yolmo "Song of Pain" (tsher glu) 
